\title{
Activation of diverse repertoires of autoreactive $T$ cells enhances the loss of anti-dsDNA B cell tolerance
}

\author{
Brian W. Busser, ${ }^{1}$ Brigette S. Adair, Jan Erikson, ${ }^{2}$ and Terri M. Laufer ${ }^{1}$ \\ ${ }^{1}$ Department of Medicine, University of Pennsylvania, Philadelphia, Pennsylvania, USA \\ ${ }^{2}$ The Wistar Institute, Philadelphia, Pennsylvania, USA
}

\begin{abstract}
$\mathrm{CD}^{+}$helper $\mathrm{T}$ cells play a critical role in the production of the antinuclear autoantibodies that characterize systemic lupus erythematosus in mice and humans. A key issue is whether this help is derived from a diverse repertoire of autoreactive $\mathrm{CD}^{+} \mathrm{T}$ cells or from a select number of $\mathrm{T}$ cells of limited specificity. We used the chronic graft-versus-host disease model to define the diversity of the $\mathrm{CD} 4^{+} \mathrm{T}$ cell repertoire required to induce the autoantibody response. By transferring clonally restricted versus clonally diverse populations of MHC class II-reactive $\mathrm{CD}^{+} \mathrm{T}$ cells, we show that the loss of $\mathrm{B}$ cell tolerance to nuclear antigens has two distinct components with different $\mathrm{CD} 4^{+}$cell requirements. Activation of limited repertoires of $\mathrm{CD}^{+} \mathrm{T}$ cells was sufficient for the expansion of anergized anti-double-stranded DNA B cells and production of IgM autoantibodies. Unexpectedly, we found that $\mathrm{CD}^{+} \mathrm{T}$ cell diversity was necessary for $\mathrm{CD}^{+} \mathrm{T}$ cell trafficking into the follicle and for the generation of isotype-switched IgG autoantibodies. Importantly, combining two limited repertoires of $\mathrm{T}$ cells provides sufficient $\mathrm{CD} 4^{+} \mathrm{T}$ cell diversity to drive antinuclear $\mathrm{Ab}$ production. These data demonstrate that a diverse $\mathrm{CD} 4^{+} \mathrm{T}$ cell repertoire is required to generate a sustained effector $\mathrm{B}$ cell response capable of mediating systemic autoimmunity.
\end{abstract}

J. Clin. Invest. 112:1361-1372 (2003). doi:10.1172/JCI200318310.

\section{Introduction}

Systemic lupus erythematosus (SLE), the prototypical systemic autoimmunity, is characterized in both mice and humans by the production of antinuclear Ab's (ANAs). ANA-producing autoreactive B cells have undergone clonal expansion and somatic mutation, changes that suggest an antigen-driven, $T$ cell-dependent process (1). A role for $\mathrm{CD}^{+} \mathrm{T}$ cells has been shown by the response of murine lupus to thymectomy, genetic deletion of MHC class II molecules, and anti-CD4 treatment (2-4). Although CD4 ${ }^{+} \mathrm{T}$ cells are clearly required for the development of murine lupus, their specific role in the loss of B cell tolerance has not been well defined.

The complexity of the $\mathrm{CD} 4^{+} \mathrm{T}$ cell repertoire required for autoantibody production has been examined. The $\mathrm{T}$ cell repertoire was restricted in $\mathrm{T}$ cell receptor-deficient (TCR-deficient) lupus-prone MRL-lpr mice to a single transgenic specificity directed against a foreign

Received for publication March 10, 2003, and accepted in revised form September 9, 2003.

Address correspondence to: Terri M. Laufer, Department of Medicine, University of Pennsylvania, Philadelphia, Pennsylvania 19104, USA. Phone: (215) 573-2955; Fax: (215) 573-7599;

E-mail: tlaufer@mail.med.upenn.edu.

Brian W. Busser's present address is: Department of Molecular Biology, Massachusetts General Hospital, Boston, Massachusetts, USA.

Conflict of interest: The authors have declared that no conflict of interest exists.

Nonstandard abbreviations used: systemic lupus erythematosus (SLE); antinuclear Ab (ANA); T cell receptor (TCR); chronic graftversus-host disease (cGVHD); T cell-B cell (T-B); H-2 ${ }^{\text {bm12 }}$ (bm12); K14- $\mathrm{A}_{\beta}^{\mathrm{b}} / \mathrm{A}_{\beta}^{\mathrm{b}-/-}(\mathrm{K} 14)$; double-stranded DNA (dsDNA); immunohistochemistry (IHC). peptide (5). These mice failed to develop high-titer autoantibodies and immune complex-mediated kidney damage, suggesting that the autoreactivity requires some $\mathrm{T}$ cell diversity. In this case, however, disease progression could require either a broader $\mathrm{T}$ cell repertoire or an autoreactive $\mathrm{T}$ cell specificity. Therefore, we sought a more thorough understanding of the diversity of the MHC class II-reactive $\mathrm{CD} 4^{+} \mathrm{T}$ cell repertoire that drives the loss of $\mathrm{B}$ cell tolerance.

Mouse models of SLE include both inbred mice that spontaneously develop SLE-like disease and experimental induction of these manifestations in nonautoimmune mice. Chronic graft-versus-host disease (cGVHD) is induced in unirradiated, MHC-incompatible mice by the transfer of allogeneic $\mathrm{CD}^{+} \mathrm{T}$ cells and results in autoantibodies and renal disease similar to human SLE (6). cGVHD is induced in normal, nonautoimmune mice and is driven by $\mathrm{T}$ cell activation. Manipulation of both the $T$ cell repertoire and the host permits a fine dissection of the $\mathrm{T}$ cell and $\mathrm{B}$ cell requirements for autoantibody production. Cohen, Eisenberg, and their colleagues have shown that, similar to inbred lupus-prone mice, cognate MHC class II-restricted interactions between donor $\mathrm{CD}^{+} \mathrm{T}$ cells and host $\mathrm{B}$ cells induce the host $\mathrm{B}$ cells to produce autoantibodies (7). $\mathrm{CD}^{+} \mathrm{T}$ cells play a critical role in the initiation and propagation of the disease, however, as in SLE, the T cell-B cell (T-B) interactions required for the production of ANAs remain poorly characterized.

To thoroughly characterize the T-B interactions required for the production of ANAs, we compared the ability of limited and diverse repertoires of MHC class II, I- $\mathrm{A}^{\mathrm{b}}$-reactive $\mathrm{CD} 4^{+} \mathrm{T}$ cells to induce ANAs in wild- 
type mice. We show that limited T cell repertoires activate autoreactive anti-double-stranded DNA (dsDNA) $B$ cells; however, these repertoires were unable to induce detectable levels of IgG ANAs. This failure was associated with follicular exclusion of MHC class II-reactive $\mathrm{CD}^{+} \mathrm{T}$ cells and suggests that multiple, diverse $\mathrm{T}-\mathrm{B}$ interactions leading to $\mathrm{CD} 4^{+} \mathrm{T}$ cell entry into the $\mathrm{B}$ cell follicle are required for the production of IgG ANAs.

\section{Methods}

Mice. All mice used were between the ages of 2 and 3 months and were on an $\mathrm{H}-2^{\mathrm{b}}$ background. C57Bl/6J, B6.PL, and $\mathrm{H}-2^{\mathrm{bm} 12}$ (bm12) mice were purchased from The Jackson Laboratory (Bar Harbor, Maine, USA). $\mathrm{H} 2-\mathrm{DM}^{-/-} \mathrm{B} 6$ mice were generously provided by Luc Van Kaer (Vanderbilt University, Nashville, Tennessee, USA) and were backcrossed onto the $\mathrm{B} 6$ background for six generations. K14- $\mathrm{A}_{\beta}^{\mathrm{b}} / \mathrm{A}_{\beta}{ }^{\mathrm{b}-/-}$ (K14) mice were backcrossed onto the $\mathrm{B} 6$ background for more than 20 generations. The 2-2-3 TCR transgene was backcrossed onto the K14 background for at least three generations. Previously, we described the development of a cutaneous autoimmune disease in approximately $20 \%$ of $2-2-3 / \mathrm{K} 14$ mice (8). Mice used in this study did not develop disease, and the $\mathrm{CD}^{+}{ }^{+} \mathrm{T}$ cells were not activated. The $3 \mathrm{H} 9 . \mathrm{KI}$ site-directed transgenic mice were generously provided by Martin Weigert (Princeton University, Princeton, New Jersey, USA) and were backcrossed onto the B6 background for at least eight generations; they were backcrossed to generate Thy $1.1^{+/+} 3 \mathrm{H} 9 . \mathrm{KI}^{+}$mice. The $3 \mathrm{H} 9 . \mathrm{KI}$ mice are on a B6 background (allotype $\operatorname{Ig} \mathrm{H}^{\mathrm{b}}$ ); in some studies, we used flow cytometry to follow the $3 \mathrm{H} 9$ heavy chain by staining with allotype-specific $\operatorname{IgD}^{\mathrm{a}}$ (see below). Genotyping of all mice was determined by PCR amplification of tail DNA and/or phenotyping of peripheral blood lymphocytes in procedures described previously (14). All mice were bred and maintained at the animal facility at the University of Pennsylvania Medical Center (Philadelphia, Pennsylvania, USA).

$C D 4^{+}$T cell isolation. Spleen and all visible lymph nodes were removed from donor mice and mashed between the frosted ends of glass slides to generate single cell suspensions. Erythrocytes were lysed by hypotonic shock $\left(0.83 \% \mathrm{NH}_{4} \mathrm{Cl}\right)$ and $\mathrm{CD}^{+}{ }^{+} \mathrm{T}$ cells isolated using a negative-selection magnetic-sorting approach. In brief, single cell suspensions were incubated with pretitrated volumes of anti-CD8 (2.43), anti-B220 (RA3-B220), antiHSA (J11d), and anti-FcR (2.4G2) hybridoma tissue-culture supernatants were grown in our laboratory. Cells were washed and incubated with magnetic bead-conjugated goat anti-rat Ig (Polysciences Inc., Warrington, Pennsylvania, USA), and non-CD4 ${ }^{+} \mathrm{T}$ cells were removed utilizing a Bio-Mag magnetic stand (Polysciences Inc.). $\mathrm{CD}^{+} \mathrm{T}$ cell purity was generally greater than $80 \%$.

CFSE. CD $4^{+} \mathrm{T}$ cells were CFSE labeled according to procedures described previously $(9,10)$. Cells were washed and resuspended at a density of $2 \times 10^{7} / \mathrm{ml}$ in PBS. An equal volume of $5 \mu \mathrm{M}$ CFSE (Molecular Probes Inc., Eugene, Oregon, USA) in PBS was added ( 5 minutes at room temperature). Labeling was stopped by addition of FBS, and cells were washed in PBS and resuspended in HBSS prior to intravenous injection. Forty-two hours later, spleen cells were stained for CD4 (see below), analyzed on a Becton Dickinson FACScalibur, and at least 1,000 live-gated $\mathrm{CFSE}^{+}$events were collected.

Experimental cGVHD protocol. Recipient mice on a B6 background were injected intraperitoneally with $10 \times 10^{6}$ purified $\mathrm{CD}^{+} \mathrm{T}$ cells in HBSS. Mice receiving the combination of the two limited $\mathrm{T}$ cell repertoires also received $10 \times 10^{6}$ total $\mathrm{CD}^{+} \mathrm{T}$ cells $\left(5 \times 10^{6} 2-2-3 / \mathrm{K} 14\right.$ $\mathrm{CD}^{+} \mathrm{T}$ cells and $5 \times 10^{6} \mathrm{H} 2-\mathrm{DM}^{-/-} \mathrm{CD}^{+} \mathrm{T}$ cells $)$. Blood samples from experimental mice were obtained at 2- to 4-week intervals, serum isolated, and frozen at $-20^{\circ} \mathrm{C}$ until analyzed. For some studies, experimental mice were sacrificed 7 days after cGVHD induction, and a small sample of the spleen was frozen in OCT for immunohistochemical analysis.

Anti-chromatin ELISA. Bovine thymus chromatin was prepared as described previously (11). Flat-bottomed Immunolon II microtiter plates (ThermoLabsystems, Franklin, Massachusetts, USA) were coated with bovine thymus chromatin $(1 \mu \mathrm{g} / \mathrm{ml})$ for 2 hours and blocked with $3 \%$ BSA $/ 0.1 \%$ gelatin $/ 3 \mathrm{mM}$ EDTA $\left(4^{\circ} \mathrm{C}\right.$, overnight). Diluted serum samples (1:500) were added in duplicate and incubated 2 hours at room temperature. Plates were washed (0.1\% Tween in PBS), and bound Ig was revealed with alkaline phosphatase-conjugated goat anti-mouse IgG or IgM (Southern Biotechnology Associates, Birmingham, Alabama, USA), using $p$-nitrophenyl phosphate (Sigma-Aldrich, St. Louis, Missouri, USA) as a substrate. The plates were read at 405-650 $\mathrm{nm}$ on a microplate reader (Molecular Devices, Berkshire, United Kingdom).

Anti-dsDNA ELISA. The anti-dsDNA ELISA was carried out according to established methods $(12,13)$. In brief, Immunlon II microtiter plates were precoated with methylated BSA (Sigma-Aldrich), washed, and coated with $50 \mu \mathrm{g} / \mathrm{ml}$ dsDNA obtained from calf thymus (Sigma-Aldrich). Plates were blocked, samples added, and bound IgG detected as above.

Total IgG. Total IgG was assessed by ELISA as described above. Plates were coated with goat antimouse IgG (Southern Biotechnology Associates) at 2 $\mu \mathrm{g} / \mathrm{ml}$. Diluted serum samples were added in duplicate, washed, and revealed with alkaline phosphatase-conjugated goat anti-mouse IgG using $p$-nitrophenyl phosphate as a substrate.

Antinuclear Ab assay. The presence of antinuclear Ab's was detected using permeabilized HEP-2 cells as the substrate (Antibodies Inc., Davis, California, USA). Serum was diluted 1:50 in 1\% BSA. Antinuclear binding was revealed using FITC-conjugated goat anti-mouse IgG (Southern Biotechnology Associates). The samples were then visualized under a fluorescent microscope and scored blind.

Flow cytometry. Live cells $\left(10^{6}\right)$ were washed in PBS containing $0.5 \%$ BSA and $0.01 \% \mathrm{NaN}_{3}$, and $\mathrm{FcR}$ was blocked with 2.4G2 (anti-FcyRII/III) tissue-culture supernatant. 


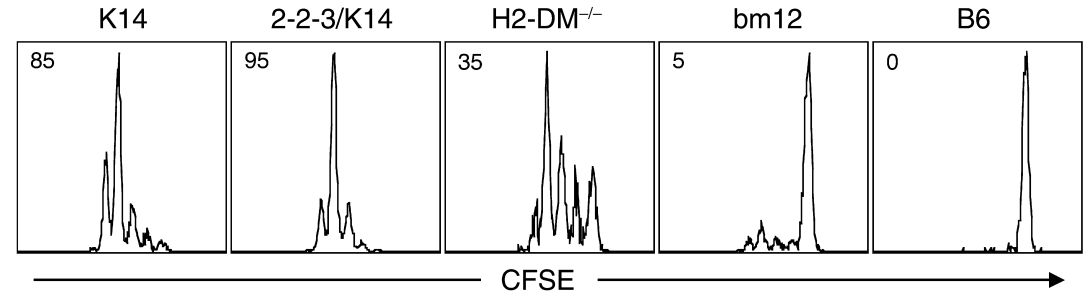

Figure 1

Proliferation of $\mathrm{I}-\mathrm{A}^{\mathrm{b}}$-reactive $\mathrm{CD} 4^{+} \mathrm{T}$ cells in $\mathrm{B} 6$ mice. $\mathrm{B} 6$ mice were injected (intravenously) with $5 \times 10^{6} \mathrm{CFSE}$-labeled CD4 ${ }^{+} \mathrm{T}$ cells. After 42 hours, animals were euthanized and spleen cells stained with anti-CD4 and analyzed by flow cytometry. Histograms show the division history of gated live splenic CFSE ${ }^{+} \mathrm{CD} 4^{+} \mathrm{T}$ cells. Percentage of $\mathrm{CD} 4^{+} \mathrm{T}$ cells responding to B6 APCs is shown in the upper-left corner of the histogram. The $y$ axis is at least 100 events for each histogram. Representative results from three independent experiments are shown.

The following dye- or biotin-conjugated Ab's were obtained from Pharmingen (BD Biosciences, San Diego, California, USA): CD4 (RM4-5), B220 (RA3-6B2), I-A (AF6-20.1), HSA (M1/69), Thy1.2 (53-2.1), B7.2 (GL1), $\lambda 1$ light chain (R11-153), CD44 (Pgp-1), CD19 (1D3), CD21 (7G6), CD22.2 (Cy34.1), and IgD (AMS9.1). Pretitrated doses of conjugated (FITC, phycoerythrin $[\mathrm{PE}]$, peridinin chlorophyll protein-cyanine 5.5 [PerCPCy5], APC, or biotinylated) Ab's were added (30 minutes, $4^{\circ} \mathrm{C}$ ). Cells were washed, and biotinylated $\mathrm{Ab}$ 's were revealed using streptavidin-allophycocyanin (SAAPC) (Pharmingen). Cells were analyzed on a Becton Dickinson Immunocytometry Systems (San Jose, California, USA) FACSCalibur using FlowJo software.

Immunohistochemistry. Spleen samples were suspended in OCT and snap-frozen in 2-methyl-butane cooled with liquid nitrogen. Spleens were sectioned and fixed with acetone and stored at $-20^{\circ} \mathrm{C}$ until stained. Samples were blocked with PBS $5 \%$ normal goat serum (Jackson ImmunoResearch Laboratories Inc., West Grove, Pennsylvania, USA) $/ 0.1 \%$ Tween- 20 and then incubated with Thy1.2-biotin (Thy1.2-bio) or $\lambda 1$ light chain-bio. Sections were washed with PBS/0.1\% Tween, and biotinylated Ab's were revealed with Vectastain $\mathrm{ABC}$ kit conjugated to HRP (Vector Laboratories, Burlingame, California, USA); substrate for HRP was 3,3-diaminobenzidine. Sections were next incubated with B220-bio, washed, and incubated with Vectastain ABC conjugated to alkaline phosphatase; substrate for alkaline phosphatase was nitroblue tetrazdium/5-bromo-4-chloro-3indolyl phosphate (NBT/BCIP). Slides were scored blind by multiple readers.

Statistical analysis. Statistical significance was determined using the Student's $t$ test.

\section{Results}

$T$ cell repertoires of limited and diverse specificities. CGVHD is induced by the transfer of allogeneic $T$ cells to unirradiated, nonautoimmune mice resulting in antidsDNA and ANA formation. We have examined the loss of B cell tolerance during cGVHD in B6 mice following the transfer of $\mathrm{I}-\mathrm{A}^{\mathrm{b}}$-reactive $\mathrm{CD} 4^{+} \mathrm{T}$ cells from four different strains of mice. Specifically, we were interested in determining how the activation and expansion of $\mathrm{I}_{-} \mathrm{A}^{\mathrm{b}}$ reactive $\mathrm{CD}^{+} \mathrm{T}$ cell repertoires of limited and diverse specificities affected the induction of $\mathrm{B}$ cell autoimmunity in cGVHD.

We have described previously K14 mice in which the expression of MHC class II on thymic cortical epithelium results in syngeneic reactivity of $\mathrm{CD}^{+} \mathrm{T}$ cells to B6 APCs (14). We subsequently derived an $\mathrm{I}^{\mathrm{b}} \mathrm{A}_{-}$ reactive TCR transgenic, 2-2-3 (V $\alpha 1$, $\mathrm{V} \beta 5$ ) from a K14 anti-B6 CD4+ $\mathrm{T}$ cell hybridoma and have shown previously that 2-2-3 TCR transgenic CD4 cells are selected on $\mathrm{K} 14$ thymic epithelium and maintain their syngeneic reactivity to B6 APCs (8). Although 2-2-3 $\mathrm{CD}^{+} \mathrm{T}$ cells can use endogenous $\alpha$ chains, the presence of the TCR transgene severely restricts the diversity of the $\mathrm{CD}^{+} \mathrm{T}$ cell repertoire.

In mice lacking H2-DM, the class II-like protein involved in removal of the CLIP peptide, the majority of I- $\mathrm{A}^{\mathrm{b}}$ molecules are occupied with CLIP (15-17). Thymic selection on this very narrow array of self-peptides selects a population of $\mathrm{CD} 4^{+} \mathrm{T}$ cells that respond to the diverse array of self-peptides expressed on wildtype $\mathrm{B} 6 \mathrm{APCs}$; however, the diversity of the $\mathrm{CD} 4^{+} \mathrm{T}$ cell repertoire is constrained $(18,19)$.

Finally, bm 12 mice are a coisogenic strain of $\mathrm{B} 6$ mice with the I-A molecules differing by only three amino acids in the peptide-binding groove; this difference is sufficient to make bm12 alloreactive with $\mathrm{B} 6$.

Thus we have used two distinct repertoires of $\mathrm{I}-\mathrm{A}^{\mathrm{b}}-$ reactive $\mathrm{CD}^{+} \mathrm{T}$ cells of limited diversity $(2-2-3 / \mathrm{K} 14$ and $\left.\mathrm{H} 2-\mathrm{DM}^{-/-}\right)$and two repertoires of $\mathrm{I}-\mathrm{A}^{\mathrm{b}}$-reactive $\mathrm{CD} 4^{+} \mathrm{T}$ cells of normal diversity (K14 and bm12). Both repertoires of diverse $\mathrm{CD}^{+} \mathrm{T}$ cells have been shown previously to be sufficient to induce cGVHD with hypergammaglobulinemia and ANA formation when transferred to naive $\mathrm{B} 6$ recipients $(6,20)$. Finally, in all experiments, transfer of syngeneic $\mathrm{B} 6 \mathrm{CD}^{+}{ }^{+} \mathrm{T}$ cells served as a negative control.

$I-A^{b}$-reactive $C D 4^{+} T$ cell repertoires proliferate to $B 6$ APCs in vivo. To verify the I- $\mathrm{A}^{\mathrm{b}}$ reactivity of the different $\mathrm{CD} 4^{+}$ $\mathrm{T}$ cell repertoires, we transferred CFSE-labeled $\mathrm{CD}^{+} \mathrm{T}$ cells into B6 mice. Figure 1 shows that all class II-reactive $\mathrm{CD} 4^{+} \mathrm{T}$ cells contained cells that proliferated, dividing at least four times by 42 hours after transfer. The individual repertoires clearly have different percentages of $\mathrm{B} 6$-reactive $\mathrm{CD}^{+} \mathrm{T}$ cells; however, this variability does not correlate with diversity. As such, the highest frequency of responding cells was the 2-2-3/K14 repertoire, whereas the lowest frequency was the bm 12 repertoire. Importantly, subsequent results suggest that the precursor frequency of $\mathrm{I}-\mathrm{A}^{\mathrm{b}}$-reactive $\mathrm{CD} 4^{+} \mathrm{T}$ cells does not determine the outcome of cGVHD.

Polyclonal B cell activation during $c G V H D$ does not lead to ANA production. To ask if the diversity of the $\mathrm{CD}^{+}$cell 
repertoire alters the induction of $\mathrm{CGVHD}$ we followed $\mathrm{B} 6$ mice that received $\mathrm{CD}^{+}{ }^{+} \mathrm{T}$ cells from $2-2-3 / \mathrm{K} 14$ and $\mathrm{H} 2-\mathrm{DM}^{-/-}$mice, the positive controls, K14 and bm 12 mice, and syngeneic $\mathrm{B} 6$ mice as a negative control. Mice were serially bled and serum was assayed for IgG levels and ANA formation.

All I-A ${ }^{\mathrm{b}}$-reactive $\mathrm{CD} 4^{+} \mathrm{T}$ cells stimulated host $\mathrm{B}$ cells to secrete IgG (Figure $2 \mathrm{a})$. The limited diversity repertoires, 2-2-3/K14 and H2-DM-/-, induced IgG levels comparable to that of the diverse K14- and bm12-positive controls. The kinetics and magnitude of IgG secretion appear different because $2-2-3 / \mathrm{K} 14$ and bm $12 \mathrm{CD}^{+} \mathrm{T}$ cells induce an early response that is not sustained in its initial intensity, whereas $\mathrm{K} 14$ and $\mathrm{H} 2-\mathrm{DM}^{-/-} \mathrm{CD}^{+} \mathrm{T}$ cells induce an early response that is sustained. These differences did not reach significance, however. Additionally, the differences in production of IgG do not correlate with T cell diversity. Therefore, all MHC class II-reactive $\mathrm{CD} 4^{+} \mathrm{T}$ cell repertoires induced polyclonal B cell activation.

To determine if polyclonal B cell activation was associated with autoimmunity, serum was assayed for IgG ANA production by indirect immunofluorescent staining of Hep-2 nuclei. Sera from B6 mice that received syngeneic $\mathrm{B} 6 \mathrm{CD} 4^{+} \mathrm{T}$ cells failed to stain Hep-2 nuclei (Figure $2 \mathrm{~b}$ ). As described previously, serum from K14 and bm12 $\mathrm{CD}^{+} \mathrm{T}$ cells induced a homogenous nuclear staining of Hep-2 nuclei indicative of anti-chromatin and anti-dsDNA Ab's. Interestingly, transfer of 2-3-3/ $\mathrm{K} 14$ and $\mathrm{H} 2-\mathrm{DM}^{-/-} \mathrm{CD}^{+} \mathrm{T}$ cells did not elicit any ANA production. The failure of $2-2-3 / \mathrm{K} 14$ and $\mathrm{H} 2-\mathrm{DM}^{-/-}$ $\mathrm{CD}^{+} \mathrm{T}$ cells to induce ANAs was confirmed by an antichromatin (Figure 2c) and anti-dsDNA ELISA (data not shown). Importantly, the production of ANAs is independent of the precursor frequency of the inducing repertoires (see Figure 1); rather, it requires diversity within the transferred $\mathrm{T}$ cells. Thus the diverse bm12 $\mathrm{CD}^{+} \mathrm{T}$ cell repertoire had the lowest precursor frequency of class II-reactive cells, but it was sufficient to induce ANAs. On the other hand, the limited diversity 2-2-3/K14 repertoire had the highest frequency of class II-reactive cells, but it was not sufficient to induce ANAs. The observation that polyclonal $\mathrm{B}$ cell activation induced by limited diversity $\mathrm{CD}^{+} \mathrm{T}$ cells does not also yield ANAs demonstrates the demanding $T$ cell requirements for breaking tolerance to nuclear antigens.

2-2-3/K14 and H2-DM-/- CD4 ${ }^{+} \mathrm{T}$ cells fail to induce ANAs in 3 H9. KI mice. To dissect the $\mathrm{T}$ and $\mathrm{B}$ cell requirements for ANA production, we used a site-directed transgenic mouse expressing the heavy chain from an anti-dsDNA $\mathrm{Ab}$ (3H9.KI) (21). "Knockin" of the $3 \mathrm{H} 9$ heavy chain into the endogenous locus allows endogenous lightchain rearrangements to generate a $\mathrm{B}$ cell repertoire
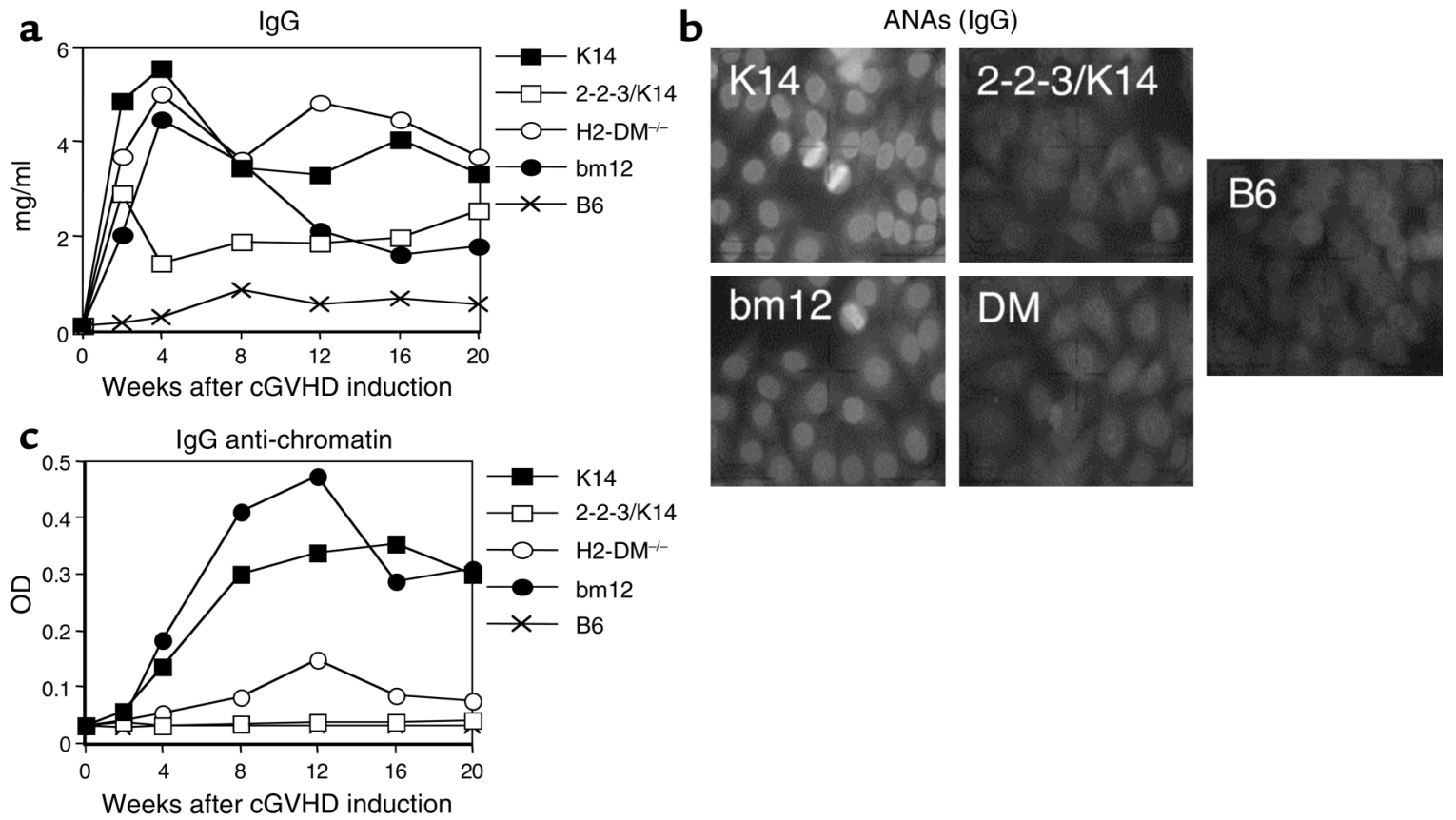

Figure 2

ANA production during CGVHD requires a diverse repertoire of CD4+ T cells. (a) cGVHD was induced in naive B6 mice. Serum was serially obtained and tested for IgG levels by ELISA. Each point represents the mean of 7-10 mice. All class II-reactive T cell repertoires stimulated a significant increase $(P<0.05)$ in total IgG at all time points tested as compared with B6 $\rightarrow$ B6. (b) Serum from mice 12 weeks after cGVHD induction was assayed for the production of IgG ANAs by indirect immunofluorescence of Hep-2 cells. B6 $\rightarrow$ B6 serum failed to stain Hep-2 nuclei (zero of eight). cGVHD induction with $\mathrm{K} 14$ (eight of eight) and bm12 (seven of seven) CD4 ${ }^{+} \mathrm{T}$ cells induced a homogenous nuclear staining, whereas cGVHD induction with 2-2-3/K14 (zero of ten) and $\mathrm{H} 2-\mathrm{DM}^{-/-}$(one of ten) $\mathrm{CD} 4{ }^{+} \mathrm{T}$ cells failed to stain the nucleus. Representative results are shown. (c) Serum from cGVHD mice was tested for the presence of IgG anti-chromatin autoantibodies by ELISA. K14 and bm12 CD4+ $T$ cells induced a significant increase in anti-chromatin autoantibodies $(P<0.05)$. 2-2-3/K14 and H2-DM-/- CD4 ${ }^{+}$T cells failed to significantly increase $(P>0.05)$ autoantibody production at all time points tested compared with B6 $\rightarrow$ B6. Each point represents the mean of $7-10$ mice. 


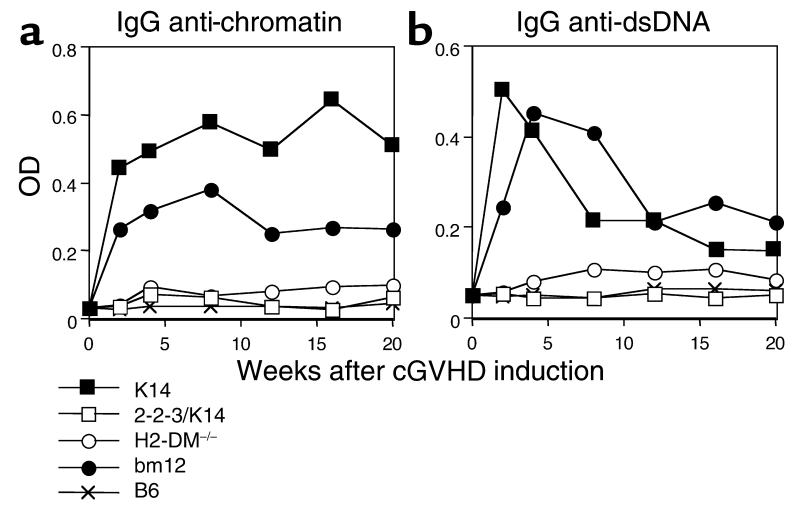

Figure 3

Introduction of an anti-dsDNA heavy chain does not alter the behavior of the class II-reactive T cell repertoires. (a) cGVHD was induced by injecting $\mathrm{B} 6 / 3 \mathrm{H} 9 . \mathrm{KI}$ mice with $10 \times 10^{6}$ of the indicated $\mathrm{MHC}$ class II-reactive $C D 4^{+} T$ cell repertoires. Serum samples were taken and tested for IgG anti-chromatin levels by ELISA. Limited T cell repertoires (2-2-3/ $\mathrm{K}_{4}$ and $\left.\mathrm{H} 2-\mathrm{DM}^{-/}\right)$failed to stimulate a significant increase in the titers of $\lg \mathrm{G}$ anti-chromatin autoantibodies as compared with B6 negative control at all time points tested $(P>0.05)$; the diverse $T$ cell repertoires induced a significant increase at all time points $(P<0.05)$. The diverse $\mathrm{T}$ cell repertoires, $\mathrm{K} 14$ and bm12, induced a comparable $(P>0.1)$ elevation of IgG anti-chromatin autoantibodies. Each group includes at least eight experimental mice. (b) Serum samples from $\mathrm{B} 6 / 3 \mathrm{H} 9 . \mathrm{KI}$ mice that received the indicated $\mathrm{MHC}$ class II-reactive $\mathrm{CD} 4^{+} \mathrm{T}$ cell repertoires were tested for IgG anti-dsDNA levels by ELISA. Similar to the failure to induce IgG anti-chromatin autoantibodies, limited $\mathrm{T}$ cell repertories (2-2-3/ $\mathrm{K}^{4}$ and $\mathrm{H} 2-\mathrm{DM}^{-/-}$) failed to stimulate a significant increase in IgG anti-dsDNA Ab production as compared with transfer of $\mathrm{B} 6 \mathrm{CD} 4^{+} T$ cells at all time points tested $(P>0.05)$, whereas activation of the diverse $T$ cell repertoires (K14 and bm12) induced a significant increase at all time points $(P<0.05)$. Each group contains at least eight experimental mice.

with both anti-DNA and non-DNA specificities. Furthermore, the $3 \mathrm{H} 9$ heavy chain, when paired with the $\lambda 1$ light chain, generates anti-dsDNA-specific $B$ cells that can be tracked (22). The anti-DNA-binding B cells in nonautoimmune $\mathrm{B} 6 / 3 \mathrm{H} 9$.KI mice are tolerant and do not spontaneously secrete anti-DNA Ab's. Sekiguchi et al. have shown that cGVHD induction with bm $12 \mathrm{CD} 4^{+}$ $\mathrm{T}$ cells results in anti-dsDNA Ab formation, including serum levels of $\lambda 1^{+}$anti-dsDNA Ab's (23).

To determine if $3 \mathrm{H} 9$.KI mice recapitulated the phenotype of wild-type B6 mice, cGVHD was induced in 3 H9.KI mice. Serum analysis of 3H9.KI mice undergoing cGVHD revealed that both $\mathrm{K} 14$ and $\mathrm{bm} 12 \mathrm{CD} 4^{+} \mathrm{T}$ cells stimulated host $3 \mathrm{H} 9$.KI B cells to secrete IgG antichromatin (Figure 3a) and anti-dsDNA Ab's (Figure 3b), whereas $\mathrm{B} 6 \mathrm{CD}^{+} \mathrm{T}$ cells did not. As in wild-type $\mathrm{B} 6$ recipients, neither $2-2-3 / \mathrm{K}_{14}$ nor $\mathrm{H} 2-\mathrm{DM}^{-/-} \mathrm{CD}^{+} \mathrm{T}$ cells induced IgG anti-chromatin or anti-dsDNA Ab's in $3 \mathrm{H} 9 . \mathrm{KI}$ mice. Therefore, skewing the repertoire of $\mathrm{B}$ cells toward autoreactivity doesn't change the requirements for a diverse $\mathrm{T}$ cell repertoire in generating ANAs.

Activation of all class II-reactive T cell repertoires induces IgM ANAs with activation and follicular entry of anti-dsDNA B cells. The behavior of anti-dsDNA-specific B cells in 3H9.KI mice can be monitored by focusing on $\lambda 1^{+} \mathrm{B}$ cells. We have previously used this strategy to show that antidsDNA B cells are regulated by anergy and exclusion from the $\mathrm{B}$ cell follicle (24). On the autoimmune-prone MRL-lpr background, a $\mathrm{CD} 4^{+} \mathrm{T}$ cell-dependent process induces the activation and follicular entry of antidsDNA B cells associated with anti-dsDNA Ab formation $(25,26)$. To distinguish transferred I-A ${ }^{\mathrm{b}}$-reactive $\mathrm{CD}^{+} \mathrm{T}$ cells from host $\mathrm{T}$ cells, the Thy1.1 allele was introduced into $3 \mathrm{H} 9 . \mathrm{KI}$ mice.

It has been difficult to detect the presence of IgM antichromatin Ab's preceding the development of IgG in mouse models of SLE (27). The controlled induction of B cell autoreactivity during cGVHD allowed us to look for IgM production. Anti-chromatin IgGs can first be detected in the serum of 3H9.KI mice 14 days after transfer of a diverse repertoire of autoreactive $\mathrm{T}$ cells. Therefore, we examined IgM ANA production prior to the induction of IgG ANAs. At day 7 after cGVHD induction, we show that activation of a diverse repertoire of class II-reactive T cells induced IgM anti-chromatin (Figure 4a) and anti-dsDNA (data not shown) Ab. Interestingly, activation of the limited $\mathrm{T}$ cell repertoires also induced IgM anti-chromatin Ab. Mice receiving a diverse $\mathrm{T}$ cell repertoire did tend to have higher titers, although this difference did not reach significance. This IgM autoantibody response includes $\lambda 1^{+}$anti-dsDNAspecific $B$ cells because the serum contains $\lambda 1^{+}$antichromatin $\mathrm{Ab}$ (data not shown), and flow-cytometric analysis revealed that the majority of $\lambda 1^{+} B$ cells are using the $3 \mathrm{H} 9$ heavy chain (data not shown). Thus, limited $\mathrm{T}$ cell repertoires induce an abortive autoantibody response that includes IgM but not IgG ANAs.

To understand the T-B interactions associated with the anti-dsDNA B cell isotype switch to IgG production, we examined the regulation of anti-dsDNA B cells on day 7. Transfer of all class II-reactive $\mathrm{CD}^{+} \mathrm{T}$ cells induced an expansion in percentage and number of splenic B220 ${ }^{+}, \lambda 1^{+}$anti-dsDNA B cells to a similar extent among all groups (Figure $4 \mathrm{~b}$ ). Furthermore, these antidsDNA B cells are phenotypically activated. Flow-cytometric analysis of $\lambda 1^{+}$anti-dsDNA B cells following cGVHD induction with all class II-reactive $\mathrm{CD} 4^{+} \mathrm{T}$ cell repertoires demonstrated an upregulation of $\mathrm{CD} 22$ (Figure 4c), B220, and I-A $\mathrm{A}^{\mathrm{b}}$ (data not shown). These data show that activation of any $\mathrm{I}-\mathrm{A}^{\mathrm{b}}-$ restricted $\mathrm{CD} 4^{+} \mathrm{T}$ cell repertoire leads to IgM anti-chromatin $\mathrm{Ab}$ production with activation and expansion of anti-dsDNA B cells.

Follicular exclusion of autoreactive $B$ cells is a second mechanism for maintaining $B$ cell tolerance to self-antigens. As such, anti-dsDNA B cell movement from the T-B interface into the follicle precedes seroconversion in lupus-prone strains. In addition, Marshak-Rothstein and her colleagues have found autoantibody-producing B cells in abnormal splenic localizations (28). To understand the splenic anatomy of ANA production which occurs during cGVHD with limited and diverse $T$ cell repertoires, $\lambda 1^{+} B$ cells from B6.PL/3H9.KI mice undergoing cGVHD were localized by immunohistochemistry 

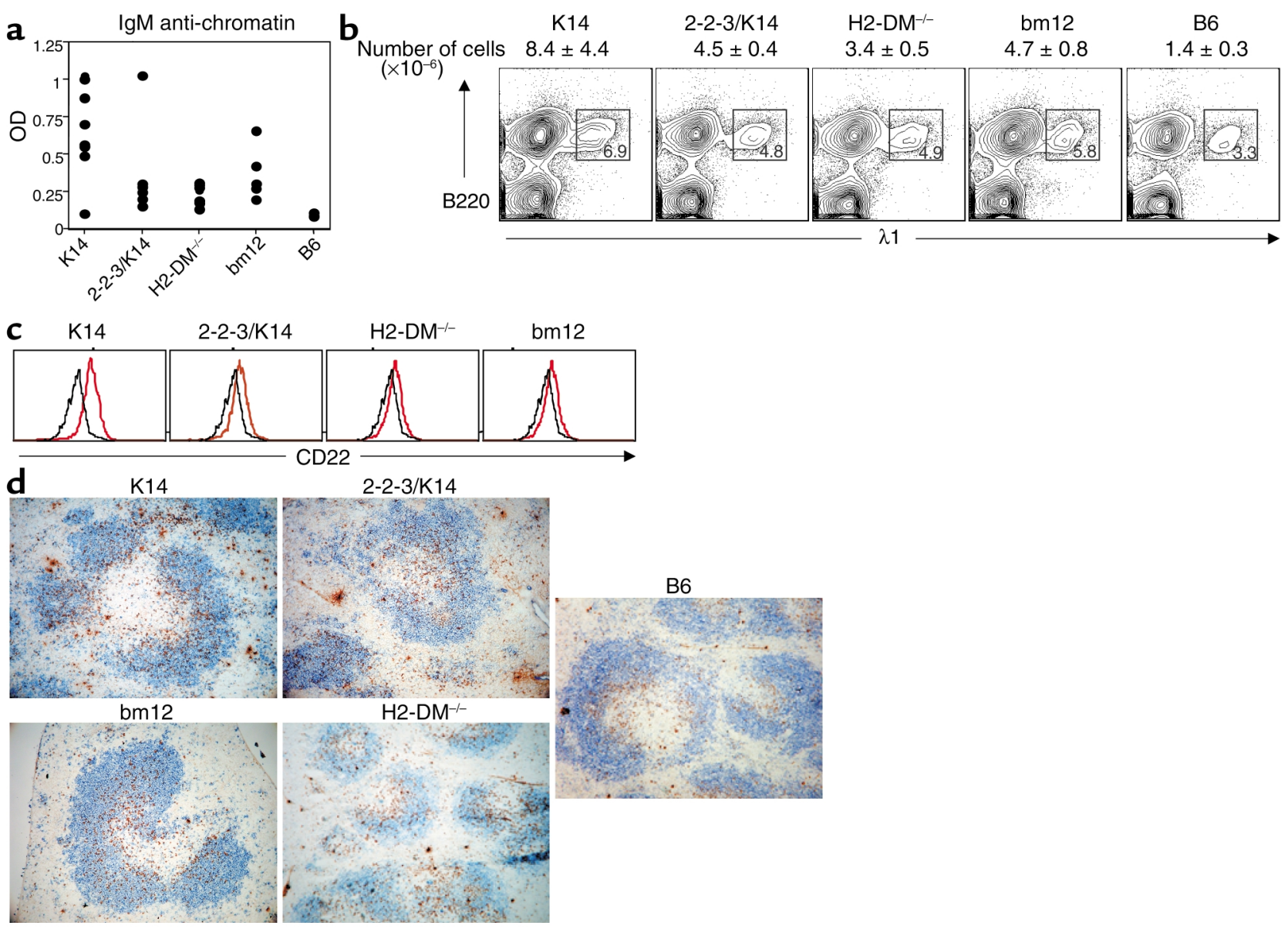

Figure 4

Activation of every class II-reactive T cell repertoire induced IgM ANAs with anti-dsDNA B cell activation and migration into the follicle. (a) Seven days after cGVHD induction, host sera were examined for the presence of IgM anti-chromatin autoantibodies. Scatter plots show IgM anti-chromatin autoantibody responses of individual mice. Recipients of every class II-reactive T cell repertoire had significantly more IgM anti-chromatin autoantibodies than $3 \mathrm{H} 9$. KI recipients of $\mathrm{B} 6 \mathrm{CD} 4^{+} \mathrm{T}$ cells $(P<0.05)$. The IgM autoantibody production was statistically similar among all recipients of class II-reactive CD4 ${ }^{+} T$ cells $(P>0.05)$. (b) Seven days after cGVHD induction, splenic anti-dsDNA B cells of B6.PL/3H9.KI hosts were identified with Ab's against B220 and $\lambda 1$. The expansion in numbers of anti-dsDNA B cells was similar among all class II-reactive T cell recipients and significantly different from the B6-injected negative control $(P<0.05$ for all groups). Representative results from four independent experiments are shown (c) CD22 expression on anti-dsDNA B cells $\left(B 220^{+}\right.$and $\left.\lambda 1^{+}\right)$. Histograms show the levels of CD22 for either B6-injected negative control (black lines) or following interaction with the indicated cell type (red lines). (d) Anti-dsDNA B cells were localized by staining spleen sections with $A b$ 's against $B 220$ (blue) and Ig $\lambda 1$ (brown). In B $\rightarrow B 6 . P L / 3 H 9 . K I$ mice, $\lambda 1^{+} B$ cells localize to the T-B interface. Seven days after CGVHD induction, all class II-reactive repertoires induced the migration of $\lambda 1^{+} B$ cells into the follicle. Representative results from four separate experiments are shown.

(IHC). In the nonautoimmune setting (transfer of B6 $\mathrm{CD} 4^{+} \mathrm{T}$ cells $) \lambda 1^{+} \mathrm{B}$ cells are localized to the T-B interface of the spleen (Figure $4 \mathrm{~d}$ ). Activation of K14 and bm12 $\mathrm{CD} 4^{+} \mathrm{T}$ cells induced anti-dsDNA $\lambda 1^{+} \mathrm{B}$ cells to scatter throughout the $\mathrm{B}$ cell follicle. Interestingly, activation of 2-2-3/K14 and $\mathrm{H} 2-\mathrm{DM}^{-1-} \mathrm{CD}^{+} \mathrm{T}$ cells also induced antidsDNA B cell migration into the follicle. Thus interaction of autoreactive anti-dsDNA $B$ cells with any repertoire of autoreactive $T$ cells leads to $B$ cell migration into the follicle. Proliferation and activation of limited repertoires of 2-2-3/K14 and $\mathrm{H} 2-\mathrm{DM}^{-/-} \mathrm{CD}^{+} \mathrm{T}$ cells leads to activation, expansion, follicular entry of anti-dsDNA B cells, and even the production of IgM ANAs. However, none of these changes are sufficient to induce the production of detectable levels of IgG ANAs. Activation of a diverse repertoire of $\mathrm{CD}^{+} \mathrm{T}$ cells is specifically required for an isotype-switched autoimmune response.

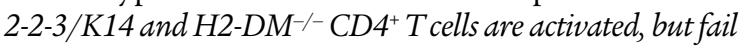
to enter the $B$ cell follicle. The production of IgG ANAs during cGVHD is directly determined by the population of $\mathrm{CD} 4^{+} \mathrm{T}$ cells studied. We therefore monitored $\mathrm{CD}^{+} \mathrm{T}$ cell responses in vivo by transferring $\mathrm{CD} 4^{+} \mathrm{T}$ cells to $\mathrm{B} 6 . \mathrm{PL} / 3 \mathrm{H} 9 . \mathrm{KI}$ mice. The increase in percentage and number of I- $\mathrm{A}^{\mathrm{b}}-$ restricted Thy $1.2^{+} \mathrm{CD}^{+} \mathrm{T}$ cells in 3H9.KI mice 7 days after transfer (Figure 5a) was comparable to that in wild-type $\mathrm{B} 6$ mice in vivo.

We next examined the splenic localization of MHC class II-reactive $\mathrm{CD} 4^{+} \mathrm{T}$ cells. Antigen-specific priming of CD4+ $\mathrm{T}$ cells occurs in the $\mathrm{T}$ cell zone $(29,30)$. A subset of these primed $\mathrm{CD} 4^{+} \mathrm{T}$ cells then migrate to the fol- 


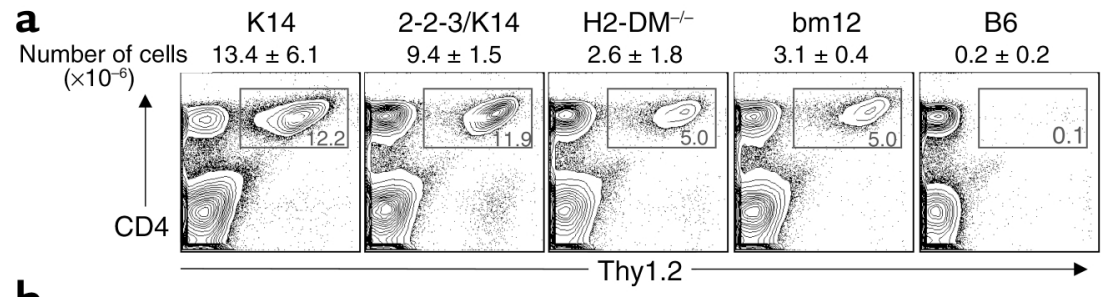

b

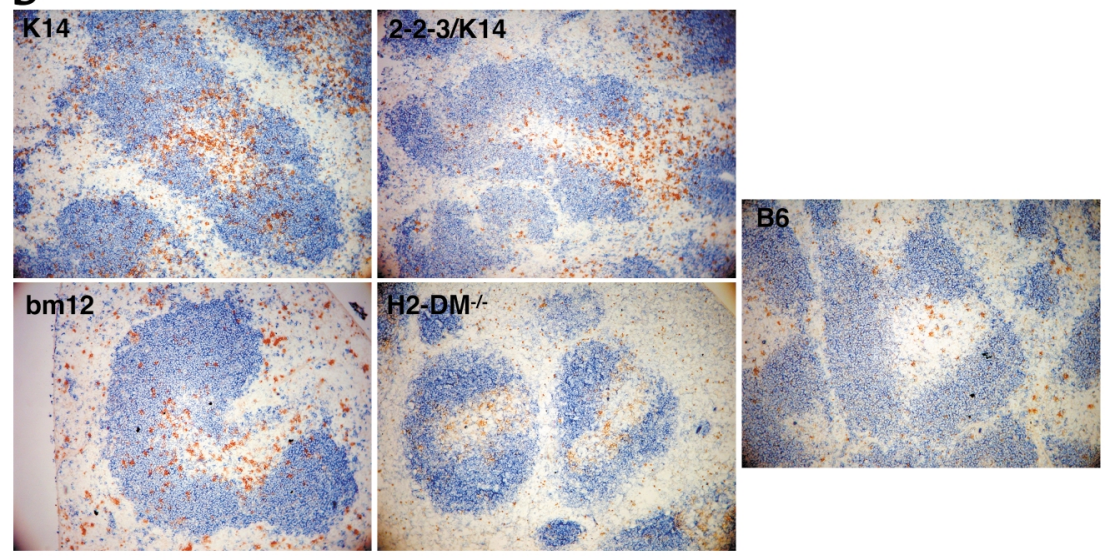

Figure 5

Limited $T$ cell repertoires are activated but fail to enter the $B$ cell follicle. (a) Donor Thy $1.2^{+} \mathrm{CD} 4$ cells were identified 7 days after induction of cGVHD in B6.PL/3H9.KI mice by staining with Thy 1.2 and CD4. Gated populations of the contour plots represent the expansion in percentage of transferred $\mathrm{CD} 4^{+} \mathrm{T}$ cells for the indicated cell population. The total number of recovered Thy $1.2^{+}$ $\mathrm{CD}^{+}$splenocytes is indicated above the plot. Representative results from four experiments are shown. (b) Donor $\mathrm{CD} 4^{+}$cells were localized by staining spleen sections with Ab's against Thy 1.2 (brown) and B220 (blue). The few B6 CD4 ${ }^{+} \mathrm{T}$ cells detected by IHC were scattered throughout the $T$ cell area. Activation of the class II-reactive $T$ cell repertoires resulted in the majority of the cells migrating to T-B interface. The diverse $T$ cell repertoires (K14 and bm12) contained T cells that were also evident in the B cell follicle; however, activation of the limited $\mathrm{T}$ cell repertoires (2-2-3/ $\mathrm{K}_{14}$ and $\left.\mathrm{H} 2-\mathrm{DM}^{-/-}\right)$did not result in the presence of transferred Thy $1.2^{+} \mathrm{T}$ cells in the follicle. Representative results of four experiments are shown.

licle to help antigen-specific $\mathrm{B}$ cells produce high-affinity, isotype-switched $\mathrm{Ab}$. In agreement with the flowcytometric data, it was difficult to detect $\mathrm{B} 6 \mathrm{CD}^{+} \mathrm{T}$ cells by IHC (Figure $5 \mathrm{~b}$ ). The small number of persistent cells could be found scattered throughout the $T$ cell zone. In contrast, activation of all class II-reactive $\mathrm{T}$ cell repertoires induced a significant expansion of cells in the $\mathrm{T}$ cell zone, with cells localizing to the T-B interface. A subset of $\mathrm{K} 14$ and $\mathrm{bm} 12 \mathrm{CD}^{+} \mathrm{T}$ cells had also translocated to the follicle, suggesting that these particular T cells may be the "helpers" of IgG ANA production. In contrast, 2-2-3/K14 and $\mathrm{H} 2-\mathrm{DM}^{-/-} \mathrm{CD}^{+} \mathrm{T}$ cells have expanded similarly within the $\mathrm{T}$ cell zone, but remain confined there.

To verify that the $\mathrm{CD} 4^{+} \mathrm{T}$ cells that entered the follicle were indeed diverse, we characterized their $\mathrm{V} \beta$ usage. Follicular entry of $\mathrm{B}$ cells is regulated by the chemokine receptor, CXCR5. CXCR5 is also expressed by a subset of $\mathrm{CD} 4^{+} \mathrm{T}$ cells, which provide "help" for $\mathrm{Ab}$ responses. The presence of follicular $\mathrm{CD} 4^{+} \mathrm{T}$ cells among the diverse $\mathrm{T}$ cell repertoires visualized by IHC correlated with an increased percentage of transferred cells expressing CXCR5 (data not shown). Importantly, the TCR V $\beta$ usage by $\mathrm{CXCR}^{+} \mathrm{K} 14 \mathrm{CD}^{+} \mathrm{T}$ cells following cGVHD induction was identical to that of the naive $\mathrm{CD} 4^{+} \mathrm{T}$ cell repertoire (data not shown). Thus, the $T$ cells that do enter the follicle are not obviously an oligoclonal subset of the cells that are activated but remain diverse. Importantly, the impaired ability to induce IgG ANAs with 2-2-3/K14 and H2-DM ${ }^{-1-}$ $\mathrm{CD}^{+} \mathrm{T}$ cells is associated with a failure to induce a follicular-homing $\mathrm{CD}^{+} \mathrm{T}$ cell population, an event that is required for $\mathrm{T}$ celldependent IgG Ab production.

Follicular exclusion of 2-2-3/K14 and $\mathrm{H}_{2}-\mathrm{DM}^{-/-} \mathrm{CD}^{+} \mathrm{T}$ cells is associated with a failure to upregulate $B 7.2$ expression on anti-dsDNA $B$ cells. Numerous TNF receptor and B7 family members are critical for $\mathrm{T}$ cell-dependent, class-switched $\mathrm{Ab}$ production; their genetic removal results in an abrogation of $\mathrm{T}$ cell-dependent $\mathrm{Ab}$ responses (31, 32). Thus, many candidates exist to describe a failure to generate class-switched $\mathrm{Ab}$; however, we focused our study on B7/CD28. In fact, mice made deficient in $\mathrm{B} 7 / \mathrm{CD} 28$ interactions do not generate a follicular-homing population of $\mathrm{CD}^{+} \mathrm{T}$ cells, which has been associated with a failure to produce class-switched $\mathrm{Ab}$ (33). Thus, we asked if the absence of $\mathrm{CD}^{+} \mathrm{T}$ cell migration into the follicle reflected an absence of B7/CD28 interactions. Anti-dsDNA $\lambda 1 \mathrm{~B}$ cells in recipients of $\mathrm{K} 14$ and bm12 CD 4 cells had increased B7.2 expression 7 days after transfer. In contrast, the $\lambda 1 \mathrm{~B}$ cells in recipients of $2-2-3 / \mathrm{K} 14$ and $\mathrm{H} 2-\mathrm{DM}^{-/}$- do not upregulate B7.2 (Figure 6). Therefore, migration of $T$ cells into the $B$ cell follicle is associated with increased B cell expression of B7.2. Thus, activation of limited repertoires of autoreactive $\mathrm{CD} 4^{+} \mathrm{T}$ cells induces anti-dsDNA B cells to become activated and enter the follicle. These interactions, however, are not sufficient to increase B7.2 expression on anti-dsDNA B cells and induce the follicular entry of class II-reactive $T$ cells and IgG ANA production.

Increasing $C D 4^{+} T$ cell diversity leads to the production of IgG ANAs. One interpretation of these data is that these two limited repertoires do not contain the particular $\mathrm{CD}_{4}{ }^{+} \mathrm{T}$ cell specificities required to interact with an anti-dsDNAspecific B cell. Alternatively, IgG ANA production could require multiple, different cognate interactions that cannot be provided by a limited repertoire of $\mathrm{CD}^{+} \mathrm{T}$ cells. To distinguish these possibilities, we examined the effect of increasing the class II-reactive $T$ cell diversity by combin- 


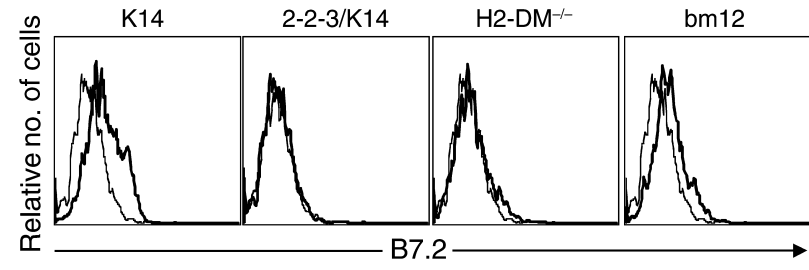

\section{Figure 6}

Loss of $B$ cell tolerance is associated with $B 7.2$ expression on antidsDNA B cells. Seven days after cGVHD induction in B6.PL/3H9. KI mice, spleen cells were stained for expression of B7.2, B220, and $\lambda 1$. Histograms show $B 7.2$ expression on gated $B 220^{+} \lambda 1^{+}$cells for mice receiving $\mathrm{B} 6$ (thin lines) or $\mathrm{I}-\mathrm{A}^{\mathrm{b}}$-reactive $\mathrm{CD} 4^{+} \mathrm{T}$ cells (thick lines). Representative results of four experiments are shown.

ing the two limited repertoires. We induced cGVHD with an equivalent number of $2-2-3 / \mathrm{K} 14$ and $\mathrm{H} 2-\mathrm{DM}^{-/-} \mathrm{CD} 4{ }^{+}$ $\mathrm{T}$ cells together or $2-2-3 / \mathrm{K} 14$ and $\mathrm{H} 2-\mathrm{DM}^{-/-} \mathrm{CD}^{+} \mathrm{T}$ cells individually. As we described earlier, 2-2-3/K14 and H2$\mathrm{DM}^{-/-} \mathrm{CD}^{+} \mathrm{T}$ cells individually failed to induce IgG antichromatin Ab's (Figure 7a). Combining these limited $\mathrm{T}$ cell repertoires, however, induced $\operatorname{IgG}$ anti-chromatin (Figure 7a) and anti-dsDNA (data not shown) Ab's to an extent comparable to that of the diverse bm12 repertoire. The combination of the two limited $\mathrm{T}$ cell repertoires induced a level of class II-reactive $T$ cell expansion similar to the other groups (data not shown). Furthermore, by using a clonotypic Ab that recognizes the 2-2-3 TCR specificity, we determined that both limited repertoires of $\mathrm{CD}^{+} \mathrm{T}$ cells have expanded similarly and are therefore participating equivalently in the autoimmune response (data not shown). Thus, IgG ANA production requires a diverse array of cognate, class II-reactive T-B interactions.

We next repeated our analysis at day 7 after cGVHD induction to determine if the loss of tolerance resulting from activating the two limited repertoires together was also associated with expression of B7.2 and follicular migration of $\mathrm{T}$ cells. Following activation with any repertoire, anti-dsDNA $\lambda 1^{+} \mathrm{B}$ cells expanded in percentage and number of cells, upregulated expression of MHC class II I-A $\mathrm{A}^{\mathrm{b}}, \mathrm{CD} 22$, and B220, and were scattered throughout the B cell follicle to an extent similar for all groups (data not shown). Importantly, combining the limited $\mathrm{T}$ cell repertoires increased B7.2 expression on anti-dsDNA B cells (Figure 7b) comparable to that seen with the diverse repertoire controls, whereas, individually, the limited $\mathrm{T}$ cell repertoires failed to upregulate B7.2 expression (Figure 6 and data not shown for this trial).

The splenic anatomy of class II-reactive $T$ cell responses were again followed by IHC. The combination of the two limited $\mathrm{T}$ cell repertoires induced a follicular homing $\mathrm{CD}^{+} \mathrm{T}$ cell population (Figure $7 \mathrm{c}$ ) comparable to the diverse repertoire controls, whereas, individually, these repertoires failed to migrate to the follicle (Figure 5 and data not shown for this trial). This result suggests that $\mathrm{T}$ cell migration into the follicle occurs following activation of a diverse repertoire of autoreactive $T$ cells.
Therefore, multiple, diverse T-B interactions are necessary for anti-dsDNA B cell expression of B7.2, T cell migration to the follicle, and IgG ANA production.

\section{Discussion}

To characterize the $\mathrm{T}$ cell requirements for the production of ANAs, we examined the ability of $\mathrm{T}$ cell repertoires of differing diversities to induce cGVHD. Transfer of autoreactive $T$ cells of limited diversity into naive nonautoimmune mice induced high levels of total IgG in the recipients, but neither IgG ANAs nor anti-chromatin Ab's; a diverse repertoire of autoreactive $\mathrm{T}$ cells was required to break B cell tolerance. Every activated repertoire of autoreactive $T$ cells caused anti-dsDNA B cell expansion, activation, and entry into the $\mathrm{B}$ cell follicle. Activation of the limited $\mathrm{T}$ cell repertoires was associated with a failure to increase expression of B7.2 on anti-dsDNA B cells and induce $\mathrm{CD} 4^{+} \mathrm{T}$ cell movement into the follicle. Importantly, combining the two limited $\mathrm{T}$ cell repertoires to increase diversity was sufficient to induce B7.2 expression on anti-dsDNA B cells,

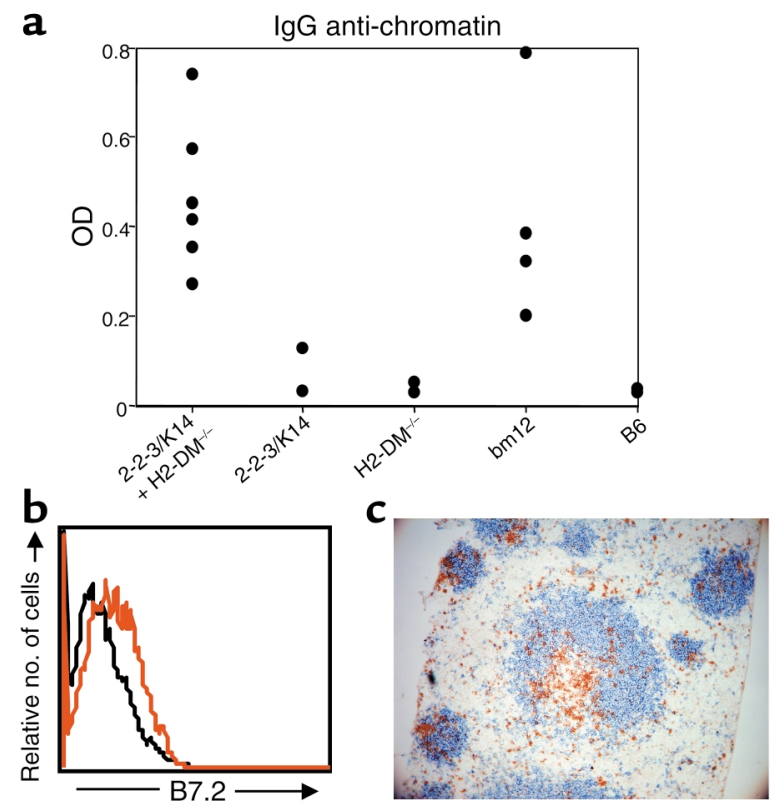

Figure 7

Increasing $\mathrm{CD}^{+} \mathrm{T}$ cell diversity is required for $\operatorname{IgG} \mathrm{ANA}$ production. (a) The indicated $\mathrm{CD}^{+} \mathrm{T}$ cell repertoires were injected into $3 \mathrm{H} 9 . \mathrm{KI}$ mice. Each recipient received a total of $10 \times 10^{6}$ cells. The scatter plots show IgG anti-chromatin autoantibody responses of individual mice 4 weeks after cGVHD induction. The IgG anti-chromatin autoantibody response elicited by 2-2-3/K14 plus $\mathrm{H}_{2}-\mathrm{DM}^{-/-} \mathrm{CD} 4^{+} \mathrm{T}$ cells was statistically similar to the response from recipients of bm 12 CD4 ${ }^{+}$T cells $(P>0.05)$. (b) Seven days after CGVHD induction, mice were euthanized and splenocytes were stained with Ab's against $B 220, \lambda 1$, and B7.2. Histograms show B7.2 expression on gated B220 $\lambda 1^{+}$anti-dsDNA B cells for the B6-transfer negative control (black line) or mice injected with the combination of the limited $T$ cell repertoires (red line). Results are representative of three experiments. (c) Spleen sections from mice receiving the combination of the limited T cell repertoires were stained for Thy1.2 (brown) and B220 (blue). Note the presence of Thy $1.2^{+}$T cells in the B cell follicle. Results are representative of three experiments. 


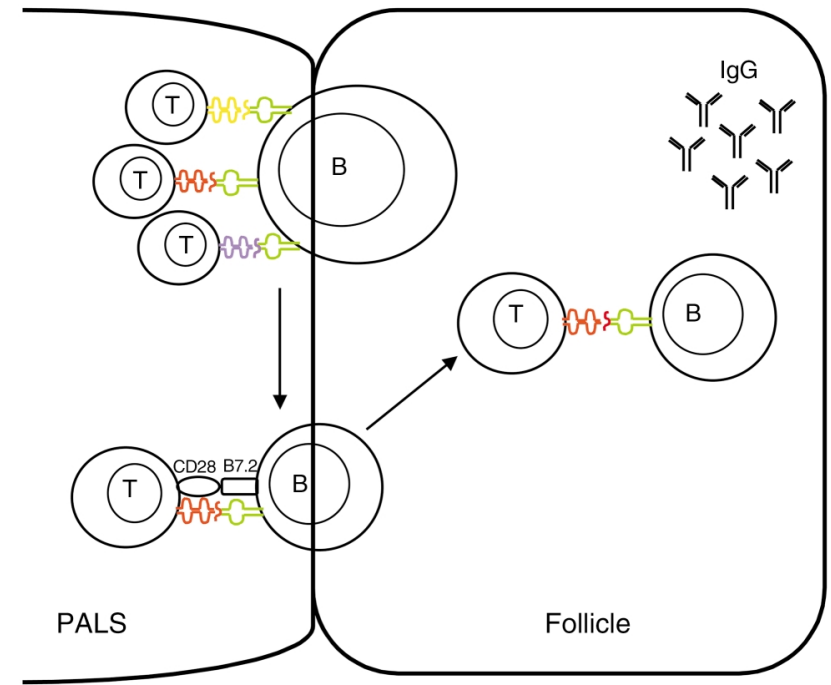

Figure 8

Activation of a diverse $T$ cell repertoire is required for the production of $\operatorname{lgG}$ ANAs. Activation of autoreactive $\mathrm{CD}^{+}{ }^{+} \mathrm{T}$ cells leads to the expansion of autoreactive anti-dsDNA B cells that enter the B cell follicle to produce IgM ANAs. Each individual anti-dsDNA B cell requires interaction with a diverse array of T cells. $T$ cell diversity is necessary to provide a pool of cells that can interact with the different MHC-peptide epitopes expressed on each autoreactive B cell. These multiple $T$ cell-derived interactions are necessary for $B 7.2$ expression on antidsDNA B cells; B7.2 expression on anti-dsDNA B cells may educate the $T$ cells to migrate into the follicle. In the follicle, T cells aid autoreactive follicular $B$ cells to produce high-affinity, isotype-switched ANAs. T, T cells; B, B cells; PALS, peri-arteriolar lymphoid sheath.

$\mathrm{CD}^{+} \mathrm{T}$ cell entry into the $\mathrm{B}$ cell follicle, and IgG antichromatin $\mathrm{Ab}$ production. These results suggest that $\mathrm{CD}^{+} \mathrm{T}$ cell diversity is required in the cGVHD system to induce isotype-switching to IgG ANA production and this reflects the requirement for movement of $\mathrm{CD}^{+}$ $\mathrm{T}$ cells into the $\mathrm{B}$ cell follicle.

Follicular localization of autoreactive $T$ and $B$ cells. Follicular exclusion of autoreactive anti-dsDNA B cells maintains $B$ cell tolerance in nonautoimmune mice (24). In lupus-prone strains, anti-dsDNA B cells can enter the B cell follicle in a $T$ cell-dependent manner $(25,26)$; this process correlates with and precedes ANA production. Interestingly, the trafficking of $\mathrm{B}$ cells is accompanied by $\mathrm{CD}^{+} \mathrm{T}$ cells moving throughout the $\mathrm{B}$ cell follicle. However, our data show that follicular entry of B cells is not sufficient for the production of IgG ANAs. Rather, follicular entry of autoreactive B cells correlated with the production of IgM autoantibodies, production of isotype-switched IgG autoantibodies, and maintenance of the autoimmune response required the additional trafficking of autoreactive $T$ cells into the follicle.

The $\mathrm{CD} 4^{+} \mathrm{T}$ cells from diverse repertoires localized by immunohistochemistry in the follicle also expressed the chemokine receptor, CXCR5 (data not shown), which mediates follicular entry of $\mathrm{B}$ cells and is also expressed by those $\mathrm{CD}^{+} \mathrm{T}$ cells that provide help for $\mathrm{Ab}$ responses. Preliminary analysis of these CXCR5positive cells suggests that the $\mathrm{CD} 4^{+} \mathrm{T}$ cells that enter the follicle are not a restricted set of $\mathrm{T}$ cells because their TCR V $\beta$ usage is as broad as that of the naive repertoire prior to activation. Thus, the diversity of the $\mathrm{T}$ cells within the follicle mirrors the diversity of the GVHD-inducing repertoire.

The role of B7.2 expression on anti-dsDNA B cells. Recent studies have shown that mice made deficient in B7/CD28 interactions do not generate a follicular-homing population of $\mathrm{CD}^{+} \mathrm{T}$ cells (33). At present, we do not know if $\mathrm{B} 7.2 / \mathrm{CD} 28$ interactions are sufficient to educate $\mathrm{T}$ cells to enter the follicle. In fact, numerous, additional, costimulatory molecules could be important for aiding $\mathrm{T}$ cell movement into the follicle. Removal of B7/CD28, OX40L/OX40, and B7RP-1/iCOS interactions (among many others) abrogates $\mathrm{T}$ cell-dependent $\mathrm{Ab}$ production (34-38). Therefore, B7.2 expression on anti-dsDNA B cells may be a "surrogate" for the failure to upregulate another costimulatory molecule. Alternatively, these costimulatory molecules may act collaboratively or sequentially for $\mathrm{T}$ cell-dependent $\mathrm{Ab}$ responses. It is tempting to speculate that B7.2 may be more than just a surrogate, however. As such, $\mathrm{T}$ cell-dependent $\mathrm{Ab}$ responses and maintenance of the germinal center require ongoing CD28/B7.2 interactions $(39,40)$. Furthermore, blockade of B7.2, but not B7.1, with mAb's prevents autoantibody production in lupus-prone NZB $\times$ NZW $F_{1}$ mice (41). Thus, it is possible that the upregulation of $B 7.2$ on antidsDNA B cells may play an important role in instructing $T$ cell migration into the follicle to maintain chronic signaling to autoreactive $B$ cells.

Why must anti-dsDNA B cells express B7.2? Why is the interaction between autoreactive $\mathrm{CD}^{+} \mathrm{T}$ cells and B7.2-expressing DCs not sufficient to mediate $\mathrm{T}$ cell movement? These data mirror previous work suggesting that B cells elicit help from $\mathrm{CD}^{+} \mathrm{T}$ cells. Thus, Stockinger, Gray, and their colleagues have shown that $B$ cell presentation of antigen to $T$ cells enhanced the differentiation of $\mathrm{T}$ cells to drive heightened $\mathrm{Ab}$ responses (42). The authors hypothesize that a certain number of T-B interactions may be necessary to induce a $B$ cell-helping $T$ cell population; our data show that a similar threshold for T-B interactions also exists in the production of Ab's to self-antigens. Thus, a self-enforcing positive-feedback loop exists between TCR/MHC class II, CD28/B7.2, and, probably, CD40/CD40L, to costimulate the $\mathrm{T}$ cell help required for the induction of a robust IgG autoantibody response.

What does a diverse repertoire of antoreactive $C D 4^{+} T$ cells provide? Although the data presented here address the biological consequences of activation of a diverse repertoire of $\mathrm{T}$ cells, they do not directly explain the necessity for anti-dsDNA B cells to interact with a diverse array of $\mathrm{T}$ cells, nor do they directly address whether diversity reflects a requirement for a specific set of rare TCR specificities. We can think of many possibilities to explain the requirement for diversity. The first is that different $\mathrm{CD}^{+}{ }^{+}$cell specificities have qualitatively different functions-in this model 2-2-3/K14 CD4s and $\mathrm{H} 2-\mathrm{DM}^{-/-} \mathrm{CD} 4 \mathrm{~s}$ would provide differing but additive 
functions to induce B cell activation. We note, however, that we have been unable to specifically identify any qualitative difference between these two populations of T cells. Importantly, cytokines such as IL-2, IL-4, IL-10, and IFN- $\gamma$ are induced similarly among all groups following activation in $\mathrm{B} 6$ mice. An alternate interpretation of this model would be that activation of limited $\mathrm{T}$ cell repertoires induces a dominant suppression of the $\mathrm{T}$ and $\mathrm{B}$ cell autoreactivity. We have shown, however, that each of these repertoires have equivalent percentages of $\mathrm{CD} 4^{+} \mathrm{CD} 25^{+}$regulatory $\mathrm{T}$ cells equally capable of suppressing an anti-B6 mixed-lymphocyte reaction (9). Furthermore, a dominant suppression model would predict that combining the two repertoires would not result in the generation of IgG ANAs. Thus, we feel that aberrant regulatory $\mathrm{T}$ cell responses cannot adequately explain our results.

The second possibility is that different $\mathrm{CD} 4^{+} \mathrm{T}$ cell specificities are required to supply the right set of TCRs necessary to interact with the different peptide/MHC complexes on $\mathrm{B}$ cells. It is possible that a particular set of rare $\mathrm{CD}^{+} \mathrm{T}$ cells can provide help to anti-dsDNA B cells in vivo. Such a model would be supported by Datta and his colleagues, who have identified histone-specific T cells, and Hahn and Wysocki's groups, who have proposed that anti-dsDNA Ab induction is driven by $\mathrm{T}$ cells specific for autoantibody-derived peptides (43-47). In these models, diversity would be required to generate sufficient numbers of these rare $\mathrm{CD} 4^{+} \mathrm{T}$ cells. Indeed, it has been suggested that terminal deoxynucleotidyl transferase deficiency ameliorates murine lupus by decreasing $\mathrm{CD}^{+} \mathrm{T}$ cell diversity, either by decreasing the overall diversity or by a failure to generate particular TCR specificities (48). Thus, in some models of lupus, the function of $\mathrm{CD}^{+} \mathrm{T}$ cell diversity may reflect a requirement for specific uncommon $\mathrm{T}$ cell receptors. Our results suggest, however, that the $\mathrm{V} \beta$ repertoire of the $\mathrm{CD}^{+} \mathrm{T}$ cells that enter the follicle and provide help do not differ significantly from the starting population of cells, arguing against an oligoclonal response.

In any model, a diverse array of TCRs is required to interact with the different MHC-peptide epitopes expressed on an individual B cell. Therefore, $\mathrm{T}$ cell diversity could also be a "readout" for MHC-peptide epitope density, and the limiting factor would be the number of interactions the $\mathrm{T}$ cell and $\mathrm{B}$ cell could undergo. Similarly, the requirement for $\mathrm{T}$ cell diversity could arise if maintenance of autoantibody production requires epitope spreading of the $\mathrm{T}$ cell response (as has been seen in other $\mathrm{T}$ cell-dependent autoimmune syndromes) (49). $T$ cell activation and differentiation could subsequently activate anti-dsDNA B cells resulting in the genesis of novel $T$ cell epitopes. A diverse $T$ cell repertoire would be necessary to recognize these epitopes and provide secondary $\mathrm{CD} 4^{+}$cell signals that are required for breaking anti-dsDNA B cell tolerance. These models are reminiscent of the model of Mamula, Shlomchik, and their colleagues who suggested that the peripheral T-B interactions in SLE constitute a pos- itive-feedback loop that allows for a self-enforcing amplification of the autoantibody response (50). Thus, the authors proposed an important role for costimulation and epitope spreading during autoreactive T-B collaboration in SLE. In any event, we envision each additional $\mathrm{T}$ cell specificity providing the anti-dsDNA $\mathrm{B}$ cells with a sufficient array of $\mathrm{CD} 4^{+} \mathrm{T}$ cell-dependent signals to break anti-dsDNA B cell tolerance. Therefore, self-perpetuating signals between $\mathrm{CD} 4^{+} \mathrm{T}$ cells and $\mathrm{B}$ cells are necessary for anti-dsDNA Ab production.

$c G V H D$ as a model system of SLE. Do these results elicited in nonautoimmune strains of mice - inform us about the loss of $\mathrm{B}$ cell tolerance and production of ANAs in lupus? Our results suggest that activation of a broad repertoire of autoreactive $T$ cell specificities must necessarily precede the development and maintenance of $B$ cell autoreactivity in nonautoimmune strains. An interesting corollary, however, is that one component of the genetic susceptibility to lupus may be a relaxation of this requirement for $\mathrm{CD}^{+} \mathrm{T}$ cell diversity - either on the B cell or the T cell side. Indeed, Wakeland, Mohan, and their colleagues have identified lupus-associated susceptibility alleles expressed in the B cell compartment that affect their activation threshold and ability to activate $T$ cells $(12,51)$. We are currently determining if these susceptibility genes decrease the $\mathrm{CD}^{+} \mathrm{T}$ cell diversity required to induce autoantibody production during cGVHD.

In summary, our results provide a model for how IgG ANAs are generated (Figure 8). Activation of autoreactive $\mathrm{CD} 4^{+} \mathrm{T}$ cells leads to the movement of autoreactive $\mathrm{B}$ cells into the follicle where $\mathrm{B}$ cells proliferate and differentiate to the production of IgM ANAs. A diverse array of cognate T-B interactions are necessary for B7.2 expression on anti-dsDNA B cells, which may educate $\mathrm{CD}^{+} \mathrm{T}$ cells to express a cell-surface receptor (such as CXCR5) important for movement into the follicle. Follicular $T$ cells help the isotype switching and generation of high-affinity anti-dsDNA Ig's. Therefore, these experiments permit us to divide the loss of B cell tolerance required for autoantibody production into two distinct components with different $\mathrm{CD} 4^{+} \mathrm{T}$ cell requirements: a nonstringent step in which $\mathrm{T}$ cell activation induces activation and proliferation of B cells, B cell movement into the follicle, and IgM secretion, and a second, stricter component in which ongoing T-B interactions lead to trafficking of $\mathrm{T}$ cells into the $\mathrm{B}$ cell follicle, isotype switching, and persistent $\mathrm{Ab}$ production. By identifying two different $\mathrm{T}$ cell-dependent components of the autoantibody response, we have provided a system in which to further investigate the pathways involved in the pathologic response.

\section{Acknowledgments}

We thank M. Weigert for generously providing 3H9.KI mice, L. Van Kaer for providing H2- $\mathrm{DM}^{-/-}$mice, and T. Lifsted for expert animal care. The authors also thank A. Bhandoola, J. Punt, M. Cancro, and members of the Laufer laboratory for helpful discussions. We thank R. 
Eisenberg for critical review of the manuscript. This work was supported by NIH grants (AI-48117 to T. Laufer and AI-32137 and AR-47913 to J. Erikson) and NIH training grant (5T32 EY-07131 to B. Busser). We also gratefully acknowledge the support of the Lupus Foundation of Southeastern Pennsylvania.

1. Shlomchik, M., et al. 1990. Anti-DNA antibodies from autoimmune mice arise by clonal expansion and somatic mutation. J. Exp. Med. 171:265-292.

2. Wofsy, D., Ledbetter, J.A., Hendler, P.L., and Seaman, W.E. 1985. Treatment of murine lupus with monoclonal anti-T cell antibody. J. Immunol. 134:852-857.

3. Jevnikar, A.M., Grusby, M.J., and Glimcher, L.H. 1994. Prevention of nephritis in major hi stocompatibility complex class II-deficient MRLlpr mice. J. Exp. Med. 179:1137-1143.

4. Steinberg, A.D., Roths, J.B., Murphy, E.D., Steinberg, R.T., and Raveche, E.S. 1980. Effects of thymectomy or androgen administration upon the autoimmune disease of MRL/Mp-lpr/lpr mice. J. Immunol. 125:871-873.

5. Peng, S.L., Fatenejad, S., and Craft, J. 1996. Induction of nonpathologic, humoral autoimmunity in lupus-prone mice by a class II-restricted, transgenic alpha beta T cell. Separation of autoantigen-specific and nonspecific help. J. Immunol. 157:5225-5230.

6. Morris, S.C., Cohen, P.L., and Eisenberg, R.A. 1990. Experimental induction of systemic lupus erythematosus by recognition of foreign Ia. Clin. Immunol. Immunopathol. 57:263-273.

7. Morris, S.C., Cheek, R.L., Cohen, P.L., and Eisenberg, R.A. 1990. Autoantibodies in chronic graft versus host result from cognate T-B interactions. J. Exp. Med. 171:503-517.

8. Fan, L., Busser, B.W., Lifsted, T., Lo, D., and Laufer, T.M. 2003. Keratinocyte presentation of antigen directs autoimmune skin disease. Proc. Natl. Acad. Sci. U. S. A. 100:3386-3391.

9. Bensinger, S.J., Bandeira, A., Jordan, M.S., Caton, A.J., and Laufer, T.M. 2001. Major histocompatibility complex class II-positive cortical epithelium mediates the selection of CD4(+)25(+) immunoregulatory T cells. J. Exp. Med. 194:427-438.

10. Wells, A.D., Gudmundsdottir, H., and Turka, L.A. 1997. Following the fate of individual $\mathrm{T}$ cells throughout activation and clonal expansion. Signals from $T$ cell receptor and CD28 differentially regulate the induction and duration of a proliferative response. J. Clin. Invest. 100:3173-3183.

11. Burlingame, R.W., and Rubin, R.L. 1990. Subnucleosome structures as substrates in enzyme-linked immunosorbent assays. J. Immunol. Methods. 134:187-199.

12. Mohan, C., Alas, E., Morel, L., Yang, P., and Wakeland, E.K. 1998. Genetic dissection of SLE pathogenesis. Sle1 on murine chromosome 1 leads to a selective loss of tolerance to $\mathrm{H} 2 \mathrm{~A} / \mathrm{H} 2 \mathrm{~B} / \mathrm{DNA}$ subnucleosomes. J. Clin. Invest. 101:1362-1372.

13. Mohan, C., et al. 1999. Genetic dissection of lupus pathogenesis: a recipe for nephrophilic autoantibodies. J. Clin. Invest. 103:1685-1695.

14. Laufer, T.M., DeKoning, J., Markowitz, J.S., Lo, D., and Glimcher, L.H. 1996. Unopposed positive selection and autoreactivity in mice expressing class II MHC only on thymic cortex. Nature. 383:81-85.

15. Miyazaki, T., et al. 1996. Mice lacking H2-M complexes, enigmatic elements of the MHC class II peptide-loading pathway. Cell. 84:531-541.

16. Fung-Leung, W.P., et al. 1996. Antigen presentation and T cell development in H2-M-deficient mice. Science. 271:1278-1281.

17. Martin, W.D., et al. 1996. H2-M mutant mice are defective in the peptide loading of class II molecules, antigen presentation, and $\mathrm{T}$ cell repertoire selection. Cell. 84:543-550.

18. Sant'Angelo, D.B., et al. 1997. The imprint of intrathymic self-peptides on the mature T cell receptor repertoire. Immunity. 7:517-524.

19. Grubin, C.E., Kovats, S., deRoos, P., and Rudensky, A.Y. 1997. Deficient positive selection of CD4 T cells in mice displaying altered repertoires of MHC class II-bound self-peptides. Immunity. 7:197-208.

20. Laufer, T.M., Fan, L., and Glimcher, L.H. 1999. Self-reactive T cells selected on thymic cortical epithelium are polyclonal and are pathogenic in vivo. J. Immunol. 162:5078-5084.

21. Chen, C., Nagy, Z., Prak, E.L., and Weigert, M. 1995. Immunoglobulin heavy chain gene replacement: a mechanism of receptor editing. Immunity. 3:747-755.

22. Radic, M.Z., Mascelli, M.A., Erikson, J., Shan, H., and Weigert, M. 1991. $\mathrm{Ig} \mathrm{H}$ and $\mathrm{L}$ chain contributions to autoimmune specificities. J. Immunol. 146:176-182.

23. Sekiguchi, D.R., et al. 2002. Chronic graft-versus-host in Ig knockin transgenic mice abrogates $\mathrm{B}$ cell tolerance in anti-double-stranded DNA B cells. J. Immunol. 168:4142-4153.
24. Mandik-Nayak, L., Bui, A., Noorchashm, H., Eaton, A., and Erikson, J. 1997. Regulation of anti-double-stranded DNA B cells in nonautoimmune mice: localization to the T-B interface of the splenic follicle. J. Exp. Med. 186:1257-1267.

25. Mandik-Nayak, L., et al. 1999. MRL-lpr/lpr mice exhibit a defect in maintaining developmental arrest and follicular exclusion of anti-doublestranded DNA B cells. J. Exp. Med. 189:1799-1814.

26. Seo, S.J., et al. 2002. The impact of T helper and T regulatory cells on the regulation of anti-double-stranded DNA B cells. Immunity. 16:535-546.

27. Burlingame, R.W., Rubin, R.L., Balderas, R.S., and Theofilopoulos, A.N. 1993. Genesis and evolution of antichromatin autoantibodies in murine lupus implicates T-dependent immunization with self antigen. J. Clin. Invest. 91:1687-1696.

28. Jacobson, B.A., et al. 1995. Anatomy of autoantibody production: dominant localization of antibody-producing cells to T cell zones in Fas-deficient mice. Immunity. 3:509-519.

29. Garside, P., et al. 1998. Visualization of specific B and T lymphocyte interactions in the lymph node. Science. 281:96-99.

30. Gulbranson-Judge, A., and MacLennan, I. 1996. Sequential antigen-specific growth of $\mathrm{T}$ cells in the $\mathrm{T}$ zones and follicles in response to pigeon cytochrome c. Eur. J. Immunol. 26:1830-1837.

31. Tivol, E.A., Schweitzer, A.N., and Sharpe, A.H. 1996. Costimulation and autoimmunity. Curr. Opin. Immunol. 8:822-830.

32. Locksley, R.M., Killeen, N., and Lenardo, M.J. 2001. The TNF and TNF receptor superfamilies: integrating mammalian biology. Cell. 104:487-501.

33. Walker, L.S., et al. 1999. Compromised OX40 function in CD28-deficient mice is linked with failure to develop CXC chemokine receptor 5-positive CD4 cells and germinal centers. J. Exp. Med. 190:1115-1122.

34. Stuber, E., and Strober, W. 1996. The T cell-B cell interaction via OX40OX40L is necessary for the $\mathrm{T}$ cell-dependent humoral immune response. J. Exp. Med. 183:979-989.

35. Tafuri, A., et al. 2001. ICOS is essential for effective T-helper-cell responses. Nature. 409:105-109.

36. McAdam, A.J., et al. 2001. ICOS is critical for CD40-mediated antibody class switching. Nature. 409:102-105.

37. Dong, C., et al. 2001. ICOS co-stimulatory receptor is essential for T-cell activation and function. Nature. 409:97-101.

38. Borriello, F., et al. 1997. B7-1 and B7-2 have overlapping, critical roles in immunoglobulin class switching and germinal center formation. Immunity. 6:303-313.

39. Han, S., et al. 1995. Cellular interaction in germinal centers. Roles of CD40 ligand and B7-2 in established germinal centers. J. Immunol. 155:556-567.

40. Nakajima, A., et al. 1997. Requirement of CD28-CD86 co-stimulation in the interaction between antigen-primed T helper type 2 and B cells. Int. Immunol. 9:637-644.

41. Nakajima, A., et al. 1995. Preferential dependence of autoantibody production in murine lupus on CD86 costimulatory molecule. Eur. J. Immunol. 25:3060-3069.

42. Stockinger, B., Zal, T., Zal, A., and Gray, D. 1996. B cells solicit their own help from T cells. J. Exp. Med. 183:891-899.

43. Zhang, X., Smith, D.S., Guth, A., and Wysocki, L.J. 2001. A receptor presentation hypothesis for $\mathrm{T}$ cell help that recruits autoreactive B cells. J. Immunol. 166:1562-1571.

44. Wang, M., Desai, D., and Marion, T.N. 1997. T cells specific for DNAbinding peptides. Lupus. 6:349-350.

45. Ebling, F.M., Tsao, B.P., Singh, R.R., Sercarz, E., and Hahn, B.H. 1993. A peptide derived from an autoantibody can stimulate T cells in the (NZB $\times$ NZW) F1 mouse model of systemic lupus erythematosus. Arthritis. Rheum. 36:355-364.

46. Singh, R.R., et al. 1995. T cell determinants from autoantibodies to DNA can upregulate autoimmunity in murine systemic lupus erythematosus. J. Exp. Med. 181:2017-2027.

47. Mohan, C., Adams, S., Stanik, V., and Datta, S.K. 1993. Nucleosome: a major immunogen for pathogenic autoantibody-inducing $\mathrm{T}$ cells of lupus. J. Exp. Med. 177:1367-1381.

48. Feeney, A.J., Lawson, B.R., Kono, D.H., and Theofilopoulos, A.N. 2001. Terminal deoxynucleotidyl transferase deficiency decreases autoimmune disease in MRL-Fas(lpr) mice. J. Immunol. 167:3486-3493.

49. Vanderlugt, C.L., and Miller, S.D. 2002. Epitope spreading in immunemediated diseases: implications for immunotherapy. Nat. Rev. Immunol. 2:85-95.

50. Shlomchik, M.J., Craft, J.E., and Mamula, M.J. 2001. From T to B and back again: positive feedback in systemic autoimmune disease. Nat. Rev. Immunol. 1:147-153.

51. Mohan, C., Morel, L., Yang, P., and Wakeland, E.K. 1997. Genetic dissection of systemic lupus erythematosus pathogenesis: Sle 2 on murine chromosome 4 leads to B cell hyperactivity. J. Immunol. 159:454-465. 